\title{
An Overview of the Law of Attorney Fees in the United States: The American Rule is not so Simple After All
}

\author{
THOMAS AlLAN HELLER
}

\begin{abstract}
It often is said that in the United States each party pays their own attorney's fees, win or lose, absent a contractual provision to the contrary or some recognized ground in equity. This basic proposition, which is true as far as it goes, is based on the so-called American Rule, which provides that in the United States each side in a litigated case is responsible for paying their own attorney, regardless of the outcome of the case. On its face this proposition seems simple. On the contrary, however, the laws in the United States governing attorney's fees are surprising quite complex. This article provides a general survey of the patchwork of laws, federal and to a lesser extent state, and the author will demonstrate that rules and laws governing attorney's fees are often grounded in important public policy and fundamentally shape important issues, such as access to the courts and the legal system more generally. Unfortunately, many United States citizens have been priced out of the legal market under the current system.
\end{abstract}

Keywords: • attorney's fees $\bullet$ fee-shifting $\bullet$ fee arrangements $\bullet$ American Rule $\bullet$ court access $\bullet$

CORRESPONDENCE AdDRESS: Thomas Allan Heller, Guest Expert and Lecturer, University of Maribor Faculty of Law, Mladinska ulica 9, 2000 Maribor, Sovenia, e-mail: heller6651@ @msn.com.

DOI 10.18690/lexonomica.10.1.45-66.2018 UDC: 347.965.7(73)

ISSN 1855-7147 Print / 1855-7155 On-line CC 2018 University of Maribor Press

Available at: http://journals.um.si/index.php/lexonomica. 
T. A. Heller: An Overview of the Law of Attorney Fees in the United States: The American Rule is not so Simple After All

American law schools traditionally have not offered core, substantive classes specifically addressing the topic of attorney's fees. Rather, the heart of the American law school curriculum focuses on familiar and traditional substantive and procedural topics such as torts, contracts, property, criminal law and procedure, civil procedure, constitutional law, legal writing and research, and legal ethics. Nor do bar examinations typically test prospective attorneys on this subject. The American lawyer graduating from law school therefore is usually left to learn about this complicated topic after entering practice. This is rather astounding and surprising when one stops to consider that in every case in which a potential consumer of legal services approaches an attorney about the possibility of legal representation initial discussions must necessarily cover the following topics: what will the services cost? Who will pay for the legal services? What kind of fee agreement will there be? Can the potential consumer afford the legal representation? ${ }^{1}$ Answers to these relatively straightforward questions are not always simple. The answers are also very important from a public policy standpoint, as they raise the issue of access to the legal system. In a functioning democracy, and one that prides itself on adhering to the rule of law, as the United States does, it is critical that all citizens, rich and poor alike, must have access to the legal system in order to exercise their rights. A surprisingly complex body of law embodied in statutes, court rules, and common law, at both the federal and state court levels, has evolved to deal with these issues. This article will provide an overview of this body of law and will briefly address the issue of whether the current laws allow all Americans adequate access to the legal system.

Chapter Two will explore practical billing issues attorneys face in every matter they handle, and correlatively, how those matters impact the legal consumer. Chapter Three canvasses typical legal fee arrangements. Chapter Four focuses on legal fees in criminal law cases, and the role the United States Constitution plays in shaping law in that area. Chapter Five discusses the unique role insurance plays in civil litigation. Chapter Six considers the role of the contingent fee arrangement. Chapter 7 then examines the differences between the American Rule and the English Rule. However, there are many exceptions to the American Rule, including: the contract exception; the bad faith exception; the common fund doctrine exception; the substantial benefit doctrine; the contempt exception; and, fee-shifting statutes. These exceptions are explored in detail in Chapter Eight. Sub-parts contained in Chapter Eight analyze fee-shifting legislation mainly federal, but to a lesser extent state - along with laws pertaining to the concept of the prevailing party and fee-shifting in insurance law cases. Chapter Nine studies miscellaneous situations where attorney's fees might be recoverable from an opponent including: for violation of discovery rules; in cases where a plaintiff brings a frivolous action or a defendant invokes a frivolous defense; under legislation designed to promote settlements; under the equitable indemnity doctrine; and, under so-called long arm statutes. Chapter Ten briefly addresses the issue of legal aid in the United States and the role it plays in providing legal representation to the many consumers that are unable to afford to hire a private attorney. The paper ends with a conclusion, that while the 


\section{LEXONOMICA \\ T. A. Heller: An Overview of the Law of Attorney Fees in the United States: The American Rule is not so Simple After All}

American Rule maintains its vitality, it is riddled with many, often complex exceptions, such that the law governing attorney's fees in the United States are both intricate and nuanced. The rules also fundamentally shape not only the amount of fees that can be earned by the attorney, but strongly impact the important policy issue of access to the legal system itself.

\section{A lawyer's time and advice is his or her stock in trade}

Abraham Lincoln famously said, "A lawyer's time and advice are his stock in trade." Lincoln's statement, made two centuries ago, still rings true today. Increasingly, the American lawyer is going into more debt to achieve a law degree. Therefore, after years of study, and often faced with a mountain of debt, most lawyers want to practice in areas where they know (or hope) they will be paid, and hopefully be paid handsomely. Therefore, new lawyers venturing into the legal marketplace after securing their bar admissions quickly begin to assess varying practice areas. Questions (not always addressed in the law schools) include what are the hot practice areas; where is money to be made; how will I be paid. In short, as in the days of Lincoln, the modern lawyer quickly faces the reality that all he or she has to offer is time, and that to be economically successful the lawyer needs to find ways to be paid for that time. On the other hand, the prospective client faces his or her own set of financial questions and concerns, some of which include: what is at stake in the legal matter? What will the cost be of pursuing the matter with the assistance of a lawyer? Who will pay the lawyer for those services? Can the prospective legal consumer afford the services of a lawyer? Is the prospective legal consumer in the end pragmatically better off foregoing the legal representation, and trying to represent him or herself alone, or simply not pursuing the legal claim or matter for which the person tried to seek legal representation?

The amount and variety of legal services provided in the United States in any given day is staggering. In 2017, there were approximately 1.34 million lawyers in the United States. $^{2}$ In 2015, there were approximately 164,830 law firms in the United States. ${ }^{3}$ Between the years 2008-2013 revenue derived from legal services ranged from approximately 245 billion to $\$ 257$ billion U.S. dollars and those figures were expected to rise to nearly 283 billion in $2017 .{ }^{4}$ Approximately $80 \%$ of the world's attorneys live in the United States. ${ }^{5}$ In recent years, approximately 15 million civil cases are filed annually in the United States courts. ${ }^{6}$ The plaintiff wins approximately $55 \%$ of all tort trials in the United States. ${ }^{7}$ A recent study found that the United States tort system cost $\$ 264.6$ billion in 2010 , which translates to $\$ 857$ per person, versus $\$ 820$ per person in $2009 .{ }^{8}$ Tort costs in 2009 were an estimated $\$ 251.8$ billion. Tort costs in 2010 therefore increased by $\$ 12.8$ billion, or $5.1 \%$. The tort costs in 2010 were the highest in United States history. ${ }^{9}$

Of course, litigation is only a part of what lawyers do. Every day lawyers are called upon to analyze problems for clients and to provide oral and written advice. They work on real estate transactions; they draft wills and trusts; they evaluate and draft contracts; they prepare documents to establish businesses, among many other things. And in each and 
T. A. Heller: An Overview of the Law of Attorney Fees in the United States: The American Rule is not so Simple After All

every such case, there are the fundamental questions: what will the cost of the legal services be; what form will the fee arrangement take; who will pay for the attorney's time?

\section{Overview of typical legal fee arrangements}

The overall costs to properly carry out a legal matter depends on numerous factors, including the amount of time the attorney must devote to the matter; the time frame in which the work has to be done (i.e., over a period of time or perhaps in a condensed time); the novelty and difficulty of the matter; staffing requirements for the matter; the length of the matter; whether the matter has to go to trial; whether there is an appeal, among many other factors. The fees a lawyer charges has many other variables as well, including the geographical location of the attorney (e.g., New York City vs. Great Falls, Montana), the lawyer's experience, reputation, skill and the lawyer's overhead expenses, etc. ${ }^{10}$ Lawyers' hourly rates vary wildly. Common fee arrangements used by American lawyers include the following: consultation fee, ${ }^{11}$ a contingency fee, ${ }^{12}$ flat fee, ${ }^{13}$ hourly rate,,${ }^{14}$ referral fees,${ }^{15}$ and retainer fees. ${ }^{16}$ The fees in some cases may be set by statute or the court may set and approve the fee the client pays.

\section{$4 \quad$ Fees in criminal cases}

In the broadest sense, there are two main classifications of law: civil law and criminal law. The issue of attorney's fees takes on a constitutional law dimension in the criminal side of the law since the $6^{\text {th }}$ Amendment to the United States Constitution provides, "In all criminal prosecutions, the accused shall enjoy the right [...] to have the Association of Counsel for his defense." The United States Supreme Court has construed the $6^{\text {th }}$ Amendment to mean that in federal courts counsel must be provided for defendants unable to employ counsel unless the right is competently and intelligently waived. ${ }^{17}$ In another famous case ${ }^{18}$, the Supreme Court considered the question of whether a criminal defendant, charged with a felony in state court (in that case Florida), was entitled to a court appointed attorney under circumstances where the defendant [charged with the crime of breaking and entering with intent to commit burglary] was indigent and thus could not afford to pay for an attorney. The Supreme Court held that the defendant was entitled to have counsel appointed pursuant to the due process clause of the Fourteenth Amendment. The appointed criminal lawyer must be paid for by the state where the prosecution is occurring.

In order to carry out the constitutional mandate of providing indigent criminal defendants with legal representation, many jurisdictions have established public defender offices, while others maintain a roster of criminal defense attorneys who will accept court appointments, and who then in turn are compensated by the state or local government where they provide the legal services. The federal government itself has a robust public defender program. 


\section{LEXONOMICA \\ T. A. Heller: An Overview of the Law of Attorney Fees in the United States: \\ The American Rule is not so Simple After All}

Estimates of the percentage of criminal defendants represented by appointed counsel generally hover at around 75-80 \% (Karlan, 1995). There is a substantial body of literature showing that the United States public defender system is under-funded and that the attorneys and staff that perform these legal services are overworked. This in turn raises serious questions whether indigent criminal defendants receive the same level of representation as criminal defendants that are able to fund their own defense team (Benner, 2011). ${ }^{19}$ It can be stated that the vast majority of attorneys that are appointed to represent indigent criminal defendants, whether at the federal or state court level, perform admirably and do a great job for their clients. On the other hand, we can also say that the $20-25 \%$ of criminal defendants that have the financial means to pay for their own legal services, and who have the means to pay for more elaborate and sophisticated legal work, such as multiple attorneys; private investigators; mock juries; unlimited research and maximum attorney effort, likely reap the benefits of those enhanced legal services in many cases. In any event, for constitutional reasons, either the federal or state governments fund much of the legal work performed in the criminal side of the law. The governments both pay prosecutors to prosecute cases and they pay lawyers to defend indigent defendants $75-80 \%$ of the time.

\section{The role of insurance in civil litigation}

Insurance plays a major role in funding legal services on the civil side of the law. This is true not only in cases which are actively being litigated, but also in cases where there is no litigation but where an insurance company is paying for legal services. ${ }^{20}$ Natural persons and legal entities purchase various types of insurance to provide protection in the event that their actions cause injury and/or damage to a person and/or property. Therefore, most persons know why it is a good idea to purchase insurance. However, the average person, and even some attorneys that do not practice in the area of insurance law, do not understand or fully understand the degree to which insurance issues affect civil lawsuits. As a matter of public policy, however, the law promotes the purchase of insurance and, as a practical matter, many civil claims and lawsuits are resolved with the use of insurance money. ${ }^{21}$

For the purposes of our discussion involving the role of insurance, we will assume we are dealing with an automobile accident, and that the at-fault driver had purchased a standard automobile insurance policy. We will further assume that when the policyholder purchased the policy, he or she purchased a policy that provided $\$ 300,000$ of coverage for liability to third persons; $\$ 50,000$ in coverage for property damage; and, $\$ 10,000$ in coverage for personal injury protection. These dollar figures are known as "limits of coverage" for the various categories of harm done, and in general, is the most the insurance carrier will have to pay on behalf of its insured. Assume that the insured is operating a covered vehicle and that his or her negligence causes both personal injury and property damage to another, who is not at fault, and to his or her self. Under this hypothetical, the most the insurance company will pay to the injured person is $\$ 300,000$ [known as "indemnity"] for his or her injuries and $\$ 50,000$ for property damages. Further, 
to the extent the insured himself or herself is injured, the most the insurance company will pay is $\$ 10,000$.

Insofar as our discussion of attorney's fees is concerned, however, the duty to defend provision is most critical. This duty means that when there is an "occurrence" (i.e., an accident of some type covered under the policy), the insurance company has the duty to assign an attorney of its choosing to represent the interests of the insured/tortfeasor throughout the pendency of the claim, whether through settlement or through trial and appeal. Legal proceedings can be prolonged and very expensive and as already discussed, millions of tort lawsuits are filed in the United States annually. The lawyer assigned to defend the case reports to both the client ("the insured") and to the insurance company that hired him or her. The assigned defense lawyer submits regular bills to the insurance company, who in turn pays for both the lawyer's time and for any out-of-pocket costs incurred by the lawyer in defending the case, such as court reporter fees; expert fees; witness fees; jury demand fees; court filing fees; interpreter fees; etc. Even in "routine" cases, legal fees and costs can amount to tens of thousands of dollars. And in many cases, pursuant to the terms of many insurance policies, there is no specific limit to the amount of legal fees and costs the insurance company is obligated to pay on behalf of its insured. Therefore, it is important to recognize that one of the main protections of an insurance policy is that the insurance company agrees to provide a defense to the insured, and is under an obligation to pay for the entire defense. Accordingly, it also is important to remember that in a high percentage of civil cases involving accidents, personal injury, and a variety of other torts, the defendant will not personally be paying the attorney's fees and costs incurred. Instead, the defendants' insurance company will pay those fees and costs. The applicability of insurance is therefore of great importance in many cases, as it offers a degree of protection to the insured and a source of recovery to the injured party.

\section{The role of the contingent fee under American law}

In Section 3 of this article, we briefly identified the contingency fee as one type of fee agreement utilized by American lawyers. The role of the contingency fee is highlighted here because of its importance in the legal system. Millions of torts claims are asserted annually. These claims are brought by personal injury attorneys and include claims stemming from dog bites, vehicular accidents, medical malpractice, among many other things. Many of the claims are meritorious, but many others are not. Personal injury lawyers invariably agree to represent their clients in these matters utilizing contingent fee agreements, meaning that the personal injury lawyer only receives a fee if the lawyer achieves either a settlement or wins a case at trial. Clearly there are many personal injury cases filed, and tried to verdict, where the plaintiff ends up losing. The central point here, however, for the purpose of our discussion, is that assuming that a person who suffers a tort injury can find a lawyer to take his or her case - and in most cases an injured person can find at least one personal injury lawyer willing to take on the case - the plaintiff does not have to worry about paying the lawyer up front (out of pocket) to fund the case. Rather, the plaintiff only pays the lawyer a percentage of any settlement recovered or 


\section{LEXONOMICA \\ T. A. Heller: An Overview of the Law of Attorney Fees in the United States:

from the amount awarded following successful litigation. In other words, it is really the lawyer, not the client, who assumes the risk of asserting a claim. Furthermore, the contingency fee agreement does promote the public policy of providing injured persons access to the courts. It is fair to say that if injured persons had to pay their lawyers on an hourly basis there would be many fewer tort claims asserted. In this important sense, the contingency fee promotes access to the courts.

\section{7}

\section{The English Rule vs. the American Rule}

The so-called English Rule provides that the losing party must pay the winning party's legal costs and attorney's fees. This rule is used in England and many other common law countries in the world. The "loser pays" rule is said to help deter frivolous claims and provide more complete compensation for the winning plaintiff (Eisenberg and Miller, 2013). In contrast, the American Rule provides that each party must bear its own costs of litigation, including attorney's fees, regardless of the outcome. The American Rule was adopted by the United States Supreme Court over 200 years ago ${ }^{22}$ and is still the rule today. In all other common law jurisdictions, the award of attorney's fees depends on the outcome of the case. The United States Supreme Court has explained the justifications for the American Rule as follows: (1) Litigation is inherently a risky proposition, and a party should not be penalized for merely participating in a lawsuit; (2) the poor would be unduly discouraged from pursuing their legal rights if they feared that losing the case would also cost them their opponents' legal fees and (3) the cost of proving the amount of legal fees would have an undue burden on judicial administration. ${ }^{23} \mathrm{~A}$ criticism of the American Rule is that it can encourage frivolous litigation and discourage meritorious litigation (Root, 2005).

\section{Six general categories of exceptions to the American Rule}

\subsection{Introduction}

As is the case in many areas of the law, the general rule, clear enough at face value, is riddled with many exceptions, all of which are complicated and worthy of lengthy discussion in their own right. But here we shall provide only an overview. The six primary exceptions, discussed briefly in turn below, are as follows: (1) contracts altering the general rule; (2) bad faith; (3) common fund; (4) substantial benefit; (5) contempt; and (6) fee-shifting statutes.

\subsection{Contract exception}

The law encourages parties to enter into contracts and to self-define the terms of their agreement. This promotes and fosters both economic activity and certainty. Parties to many contracts include provisions that the prevailing party shall be entitled to the recovery of attorney's fees and the costs of litigation. Courts will generally enforce contractual fee-shifting provisions, except in unusual cases where they are deemed to be 
T. A. Heller: An Overview of the Law of Attorney Fees in the United States: The American Rule is not so Simple After All

contrary to public policy, such as where one party to the contract is the more powerful party to the contract and drafts the provision. An example of an unenforceable attorney fee provision might be where an insurance company attempts to make its insured liable for attorney's fees in suits where the insurance company is successful. In civil law countries the "weak-party doctrine" might negate such clauses. ${ }^{24}$

\subsection{The bad faith exception}

The Supreme Court has held that a federal court has discretion to award attorney's fees to a successful party when the other side has acted "in bad faith, vexatiously, wantonly, or for oppressive reasons." ${ }^{25}$ According to the court, the underlying rationale for "feeshifting" in such cases is "punitive" and the essential element in triggering the award of fees is the existence of "bad faith" on the party of the unsuccessful litigant. According to the Court, "bad faith" might be found not only in the actions that led to the lawsuit itself, but also in the actual conduct of the litigation. ${ }^{26}$ An attorney, as well as a party, who acts in bad faith may be ordered to pay the attorney's fees of the opposing party. The Supreme Court has held that federal courts have the inherent powers to sanction bad faith conduct, and that this power extends to both members of the bar and to the litigants before it. ${ }^{27}$ Public policy drives this exception by awarding attorneys' fees against parties who litigate in bad faith, for the clear purpose of deterring illegitimate behavior in the courtroom, and sometimes outside of it.

\subsection{The common fund exception}

What is known as the common fund or common benefit exception, provides that "in the absence of a statutory prohibition, the federal courts have authority to award attorneys' fees from a fund to a party who, having a common interest with other persons, maintains a suit for the common benefit and at his own expense, resulting in the creation or preservation of a fund, in which all those having the common interest share." 28 This exception to the American Rule does not shift the cost of paying attorney's fees to the losing party, but rather to those who benefit from the suit, and the fund created thereby. The common fund doctrine was originally conceived in a case against trustees of ten or eleven million acres of land who had collusively sold hundreds of thousands of those acres at nominal prices. One beneficiary, after eleven years of litigation at his own expense, recaptured the assets and presented a claim for reimbursement of attorney's fees. The Supreme Court approved the award, writing that "if the complainant is not a trustee, he has at least acted the part of a trustee in relation to the common interest." 29 The doctrine's main purpose is to compensate parties who create or preserve a common fund for the benefit of others.

The Supreme Court has offered three main reasons in support of the common fund exception: (1) It would be unjust for the plaintiff to bear all of the costs of litigation when there are other beneficiaries of the same class or group; (2) nonparticipating beneficiaries would have an unfair advantage; and (3) courts of equity historically have awarded 


\section{LEXONOMICA \\ T. A. Heller: An Overview of the Law of Attorney Fees in the United States:

attorney's fees from court-controlled funds when the suit of one creditor would benefit other creditors in a bankruptcy proceeding, with the legal fees coming out of the bankrupt assets. ${ }^{30}$ Three conditions must be met before the litigation expense will be spread over a number of parties: First, a fund must exist. Second, a court must be able to exert control over the fund. Third, the fund beneficiaries must be identifiable so the court can shift the attorney's fees to those benefiting from the litigation (Cubita, Lichtman and Rubino, 2012: 280-281). While the common fund exception to the American Rule is applied in many situations, most commonly it is employed in antitrust litigation; mass disaster torts; stockholders' derivative suits; and, class action suits.

\subsection{Substantial benefit exception}

Closely related to the common fund doctrine is the substantial benefit rule, as both force nonparties to share in the litigation expenses and disallow absent parties to be unjustly enriched at the cost of the party bringing the suit. Like the common fund doctrine (absent the fund), the court must exert some control over an entity composed of beneficiaries in order to disperse the fee award. However, the key difference between the two doctrines is that the substantial benefit doctrine applies to non-pecuniary (i.e. something other than money) benefits as well as to pecuniary benefits (Cubita, Lichtman and Rubino, 2012: 280-281).

\subsection{The contempt exception}

A much less used exception to the American Rule can be found in contempt proceedings. The Supreme Court has held that a party can collect attorney's fees for the enforcement of a contempt order when seeking to enforce a judgment through contempt proceedings. ${ }^{31}$ To determine which fees will be awarded, and when, the court looks to the willfulness of the contempt.

\subsection{Fee-shifting statutes}

\subsubsection{Overview of federal fee-shifting statutes}

Probably the most meaningful, extensive and complicated, exception to the American Rule can be found in statutory shifting of attorney fees. There are hundreds of federal and thousands of state statutes allowing the shifting of fees (Vargo, 1993: 1588). Many of these statutory exceptions to the American Rule are based on the concept of the so-called Private Attorney General doctrine, which provides that a plaintiff should be awarded attorney's fees when he or she has effectuated a strong Congressional policy which has benefitted a large class of people, and where further the necessity and financial burden of private enforcement are such as to make the award essential. ${ }^{32}$ Fee-shifting statutes at the federal court level can be divided into four main categories:

- Civil rights suits, such as the Fair Housing Amendments Act of 1988, 42 U.S.C. $\S 3613(c)(2)(2004)$; 
T. A. Heller: An Overview of the Law of Attorney Fees in the United States: The American Rule is not so Simple After All

- Consumer protection suits, such as the Equal Credit Opportunity Act, 15 U.S.C. $\S 1691 \mathrm{e}(\mathrm{d})(2004)$;

- Employment suits, such as the Fair Labor Standards Act, 29 U.S.C. §216(b)(2004); and

- Environmental protection suits, such as the Clean Air Act, 42 U.S.C. $\S 7604(d)(2004)$.

The United States Congress has passed these categories of legislation, and many other statutory provisions shifting fees, because they compel a higher public purpose and because the successful plaintiff in these types of cases should not have to shoulder the costs of advancing American public policy, especially in cases where the successful plaintiff does not always obtain a monetary award. This type of legislation advances the goal of making access to courts easier for litigants with strong cases, and embodies a policy of social reform through litigation, especially in many cases that would not yield plaintiffs a financial award from which a contingent fee may be paid. Furthering these policies and sustaining consistency, these statutes grant fees to virtually all prevailing plaintiffs while denying them to virtually all prevailing defendants. In other words, these are one-sided fee-shifting statutes.

\subsubsection{The concept of prevailing party}

Undoubtedly, these statutes have made it easier for many plaintiffs to gain access to justice, and therefore have fulfilled their primary mission. And, reflecting back on comments made in section two of this article, American lawyers coming out of law school have seized upon the many fee-shifting statutes as a way of developing their own niches in a competitive legal market. Therefore, these statutes have, in a real sense, been beneficial not only to segments of the public that can avail themselves of them, but also to a large segment of industrious lawyers that are always on the lookout for new feeshifting legislation, as each such newly enacted statute constitutes the next potential job opportunity. ${ }^{33}$ However, the fee-shifting language used by Congress has not been consistent, which itself has led to litigation, and the need for the courts, including appellate courts, to interpret Congressional intent. ${ }^{34}$ The courts also have had to grapple with thorny issues of what exactly constitutes a "prevailing party." Most federal feeshifting provisions authorize courts to award fees if the fee claimant was the "prevailing party," the "substantially prevailing party," or is "successful." But making these determinations is not always simple.

It has been stated that, "the touchstone of the prevailing party inquiry must be the material alteration of the legal relationship of the parties in a manner which Congress sought to promote in the fee statute. ${ }^{35}$ For example, many federal Courts of Appeal have ruled that relief obtained via a preliminary injunction can, under appropriate circumstances, render a party "prevailing." ${ }^{36} \mathrm{~A}$ "prevailing party" is not limited to a victor only after entry of a final judgment following a full trial on the merits. To the contrary, fee awards are often granted upon favorable settlements, as such an outcome encourages settlements, lessens 


\section{LEXONOMICA \\ T. A. Heller: An Overview of the Law of Attorney Fees in the United States: \\ The American Rule is not so Simple After All}

docket congestion, and prevents losing parties from escaping liability for fees merely by conceding cases before final judgment, all of which are valid public policy objectives. ${ }^{37}$

In appropriate cases, a declaratory judgment, without any monetary award, can form the basis for a fee award, so long as the judgment affects the behavior of the defendant toward the plaintiff. ${ }^{38}$ In a case under the Clean Air Act, the Supreme Court held that Section 307(f) of the Act authorizes awards of attorney's fees only to plaintiffs who have "some degree of success on the merits." 39 This statute, as well as other federal environmental laws, provides: "In any judicial proceeding under this section, the court may award costs of litigation (including reasonable attorney and expert witness fees) whenever it determines that such an award is appropriate." On their face, these statutes allow fee awards even to parties who do not "prevail," and, in the case under consideration, the Court of Appeals had awarded fees to such a party, holding that it was "appropriate" for it to receive fees for its contributions to the goals of the Clean Air Act. The Supreme Court, in discussing the rationale for its ruling, observed that Congress, in its use of specific wording in the statute, meant only "to expand the class of parties eligible for fee awards from prevailing parties to partially prevailing parties - parties achieving some success, even if not major success." In another case, the Supreme Court noted that "plaintiffs may be considered 'prevailing parties' for attorney's fees purposes if they succeed on any significant issue in litigation which achieves some of the benefit the parties sought in bringing suit." ${ }^{40}$ In discussing how to determine the amount of fees that were reasonable when the plaintiff only achieved limited success, the court stated: "There is no precise rule or formula for making these determinations. The district court may attempt to identify specific hours that should be eliminated, or it may simply reduce the award to account for the limited success. The court essentially has discretion in making this equitable judgment." ${ }^{41}$

In another case with the question of what to do in the case the plaintiff scores a partial, and not complete victory, the Supreme Court held that under 42 U.S.C. $\$ 1988$ (b) that although a party must prevail on a "significant" issue in order to be eligible for a fee award, it need not prevail on the "central" issue in the litigation. Rather, the degree of the plaintiff's success in relation to the other goals of the lawsuit is a factor critical to the determination of the size of a reasonable fee, not to the eligibility for a fee award at all. ${ }^{42}$ In another case, the plaintiff was awarded only one dollar (i.e., a nominal award of damages) when he sought $\$ 17$ million under 42 U.S.C. $\$ 1988(b)$. There, although the plaintiff technically "prevailed," nevertheless since he failed to prove an essential element of his claim, namely the entitlement to damages, the Supreme Court ruled he was not entitled to any award of attorney's fees. ${ }^{43}$

In order of advancing the public policy that encourages parties to settle their disputes, litigants can stipulate to an award of reasonable attorney's fees in their settlement agreement (see, Bucklin, 2006). 
T. A. Heller: An Overview of the Law of Attorney Fees in the United States: The American Rule is not so Simple After All

\subsubsection{State fee-shifting statutes - an example from Washington State}

The fifty state legislatures have each enacted legislation that shifts fees in cases where the state legislatures have determined that there are compelling public policy reasons for doing so. The following is one example of a fee-shifting statute recently enacted in Washington State. The law jealously guards one's interest in real property. However, the doctrine of adverse possession recognizes that if a person uses another's real property: exclusively; continually; adversely (i.e., without permission); and, for a statutorily defined period of time (e.g., 10 years) without the true, title owner taking action to oust the interloper, then the non-owner is said to have "adversely possessed" the property and that person then becomes the title owner to the property adversely possessed. There has been extensive litigation in Washington over property with many cases in the courts involving adverse possession and related doctrines. The Washington State legislature recently passed legislation regarding adverse possession, and added the following fee shifting provision: "(3) The prevailing party in an action asserting title to real property by adverse possession may request the court to award costs and reasonable attorneys' fees. The court may award all or a portion of costs and reasonable attorneys' fee to the prevailing party if, after considering all the facts, the court determines such an award is equitable and just. ${ }^{44}$

\subsubsection{Fee-shifting in insurance setting}

In light of the important role that insurance plays in helping to control risk, and the special relationship that exists between the insurer and the insured (again, the so-called "weakparty" concept), in some cases involving insurance contracts, courts have been willing to award attorney's fees to the insured even in the absence of a contractual attorney's fee provision in the policy. The insured, for example, may be entitled to attorney fees after bringing a successful action to secure coverage under the policy of insurance. In Washington State, this doctrine has become known as the Olympic Steamship rule. The Washington State Supreme Court held that an insured party has the right to recover attorney's fees incurred as a result of the insurance company's wrongful refusal to provide a defense. ${ }^{45}$ The rule also authorizes an award of attorney's fees to the insured for a successful appeal. ${ }^{46}$

\subsubsection{Conclusion}

Fee-shifting legislation has therefore had a dramatic impact on litigation both at the federal and state court levels. Legislation of this nature is a major paradigm shift from the basic American Rule of each party paying their own fees, win or lose. In some cases, feeshifting legislation makes it easier for some parties to gain access to the courts, ${ }^{47}$ but at the same time such legislation provides economic incentives for litigants to resolve disputes prior to trial (or even without litigation at all) due to the economic risks (and uncertainty) inherent in the losing party paying the opponent's attorney's fees and costs. ${ }^{48}$ 


\section{LEXONOMICA \\ T. A. Heller: An Overview of the Law of Attorney Fees in the United States:

In all cases, the legislating authorities made institutional value judgments that for various public policy reasons exceptions should be made to the American Rule.

\section{Miscellaneous situations where attorney's fees may be recoverable}

There are numerous other instances, not previously discussed, where one party may seek to obtain an award of attorney's fees or costs from the other side. The rules vary from jurisdiction to jurisdiction and it is not possible to survey all of these rules in this article. However, some common situations will be discussed, and these examples again help make the point that special court rules; special legislation; and, common law decisions by the courts have led to many deviations and departures from the American Rule, and have had the effect of encouraging parties to resolve their disputes when at all possible but also to litigate fairly and honestly with each other when litigation is pending.

\subsection{Costs and attorney's fees for violations of discovery rules}

Unlike in civil law jurisdictions, in common law jurisdictions such as the United States, large portions of a litigated case are devoted to what is known as pretrial discovery. Federal court civil procedure is governed by the Federal Rules of Civil Procedure (FRCP), and the discovery rules are generally set forth in FRCP 26-37. State courts have civil rules of procedure that are heavily influenced and patterned after the federal rules. Discovery tools include the use of written interrogatories ${ }^{49}$ requests for production of documents, ${ }^{50}$ requests for admissions,${ }^{51}$ depositions,${ }^{52}$ and requests for physical and mental examinations in cases where such issues are in dispute. ${ }^{53}$ The civil rules, along with case law construing them, provide that these discovery tools are to be utilized liberally and the parties are expected to work together in a cooperative spirit with the court becoming involved only when impasses are reached (Speck, 1951: 1132-1134). The courts expect all counsel and parties to work together cooperatively, even though the system is adversarial at its core. The general notion is that open and free discovery will enable all sides to "discover the truth", including the strengths and weaknesses of the case; will therefore lead to settlement of disputes in most cases; and, where cases do not settle and end up in trial, theoretically there will be no surprises.

Where there are discovery disputes and the parties cannot resolve those disputes on their own, the court intervenes upon motion by the aggrieved party and issues written discovery orders. The procedures for such motions are contained in FRCP 37 and the various state analogues the same. Although the case law varies somewhat from jurisdiction to jurisdiction, the law, put simply, is that a court has the power to enter sanctions against a party that fails to comply with the discovery rules or breaches a discovery order. There is a "pecking order" of sanctions starting with less onerous ones that might include small fines or orders to pay attorney's fees (say \$500); to more extensive awards of attorney's fees; to the exclusion of evidence at trial; to so-called adverse inference instructions, where the jury is instructed that it may or shall presume evidence the non-complying party lost or failed to produce was adverse to it ${ }^{54}$; all the way to the most severe sanctions of 
T. A. Heller: An Overview of the Law of Attorney Fees in the United States: The American Rule is not so Simple After All

all: dismissal or default. These most severe sanctions are employed by the court where the non-complying party has engaged in a pattern of willful non-compliance with court orders or otherwise has flagrantly violated the rules in some way. The Morgan Stanley and Zubulake cases, discussed in footnote 54, and many other like them, highlight the fact that violations of the court rules and discovery orders often result in fee and cost shifting and in related rulings that can dramatically tilt the outcome of litigation.

\subsection{Recovery of attorney's fees in cases involving a frivolous action or defense}

There are statutes in some states that permit the court to award to the prevailing party reasonable expenses and attorney's fees, upon a written finding by the court that the losing party's action, counterclaim, cross-claim, third-party claim, or defense was frivolous and advanced without reasonable cause. ${ }^{55}$ Under such a statute in Washington State, attorney's fees may not be awarded unless the claim or defense is frivolous in its entirety. Thus, if any of the claims or defense has merit, then the action is not deemed frivolous and attorney's fees may not be awarded. ${ }^{56}$ Still, these kinds of statutes, in instances where they apply, deviate from the basic American Rule.

\subsection{The principle of equitable indemnity}

There is a principle of law known as "equitable indemnity." The rule is as follows: where the acts or omissions of a party to an agreement or event have exposed the other party to litigation with a third party unconnected with the initial agreement or event, equity allows a court to award attorney's fees to the innocent party as an element of consequential damages in an action against the party exposing the plaintiff to litigation. ${ }^{57}$ Again, this is an example of a situation where a court, sitting in equity, can step in and compensate an innocent party that has been wronged, due to no fault of its own, and such compensation can include an award of attorney fees and costs. The principle is rooted in sound public policy and again is a sensible departure from the basic American Rule.

\subsection{Fee shifting after settlement offer not accepted}

The law often utilizes various mechanisms to encourage parties to settle their disputes, thereby avoiding court congestion and expense of litigation..$^{58}$ One such example can be found in Washington State, which has a statute providing that in any action for damages where the amount pleaded by the prevailing party is $\$ 10,000$ or less, a reasonable attorney's fee shall be taxed as a party of the costs awarded to the prevailing party.$^{59}$ This statute applies to tort and contract actions, and to actions to foreclose on mechanics' liens, and applies only to actions for damages. "Prevailing party" is used in a different sense in this statute. Here, the plaintiff is the prevailing party only if the plaintiff's recovery, exclusive of costs, is as much as or more than the amount offered in settlement by the plaintiff. The defendant is the prevailing party if the recovery is as much as or less than the amount offered in settlement by the defendant, or if the plaintiff recovers nothing. 


\section{LEXONOMICA \\ T. A. Heller: An Overview of the Law of Attorney Fees in the United States: \\ The American Rule is not so Simple After All}

\subsection{Recovery of attorney's fees to non-resident defendant}

Some states, including Washington, have what are known as long-arm statutes. Under the Washington statute ${ }^{60}$ the court is permitted to award reasonable attorney's fees to a nonresident defendant who was served outside the state but prevails in the action. Attorney's fee awards are not limited to cases in which the defendant prevails on the merits. Attorney's fees may likewise be awarded when then defendant obtains a dismissal for lack of jurisdiction, or even when the plaintiff takes a voluntary dismissal. ${ }^{61}$ When attorney's fees are awarded, the amount should be limited to an amount necessary to compensate the defendant for the added burden of being brought into the foreign court system pursuant to the long-arm statute. ${ }^{62}$ In other words, this is an example of a partial fee-shifting provision, and does not authorize the court to award all of the defendant's reasonable attorney's fees in defending the action. Still, this is yet another example of legislative efforts meant to help ensure that plaintiffs' attorneys stop and think before hailing foreign defendants into a local court; and to make them reflect on whether the claim against the foreign defendant truly has merit, for if it does not, the plaintiff faces the serious risk of an adverse attorney fee award.

\section{$10 \quad$ Legal aid in the United States}

The sad but unfortunate truth is that the costs associated with legal services in the United States has priced many people out of the market, meaning that they are either foreclosed from the legal system entirely or they have to represent themselves. ${ }^{63}$ Legal aid in the United States is different for criminal law and civil law matters. As discussed earlier, under the United States Constitution criminal legal aid with legal representation is guaranteed to defendants under criminal prosecution who cannot afford to hire an attorney. Civil legal aid, on the other hand, is not guaranteed under the law, but is provided by a variety of public interest law firms and community legal clinics either for free or at a reduced cost. The entities providing these services may impose income ceilings as well as restrictions on the types of cases they will take, because there are always too many potential clients and not enough money to go around. Common types of cases undertaken by civil legal aid organizations include the denial or deprivation of government benefits, evictions, domestic violence, immigration status, and discrimination. Most legal aid work involves counseling, informal negotiation, and appearances in administrative hearings as opposed to formal litigation in the courts. ${ }^{64}$

This issue is briefly discussed in this article because, as we have seen from the discussion above, despite the American Rule, which states that each side is responsible for their own attorney's fees, there are in fact large segments of litigants/legal consumers that do not really have to worry about that rule. One example is indigent criminal defendants who have a constitutionally protected right to assigned counsel. Another prime example are the many civil court defendants who are assigned counsel by their insurance company, which in turns pays defense counsel and funds litigation expenses. And as we have seen, the multitude of fee-shifting statutes facilitate the assertion of claims by certain protected classes of claimants that might not otherwise have the financial wherewithal to assert such 
claims in the absence of statute. And as we have already seen, in the civil arena, especially where personal injury claims of varying types are asserted, the plaintiffs' counsel primarily bears the financial risk of pursing litigation by taking such cases on a contingency fee basis. Plaintiffs in those cases have little to lose by bringing claims (about 15 million a year) since it is mainly their legal counsel that is taking the financial risk of pursing the claims.

On the other hand, a fundamental problem, leading to issues of proper access to the courts (Buckwalter-Poza, 2016), is that many lower middle class people have "too much income" to qualify for legal aid, but "not enough money" to pay for the services charged by private attorneys. Many of those persons are frozen out of the legal system entirely, or they try to represent themselves in court, often with disastrous results (Nichols, 2015: 198, 207). Some commentators have proposed that mandatory attorney pro bono obligations ought to be required of all lawyers in the United States. Most bar associations in the United States merely strongly encourage attorneys to participate in pro bono activities, but do not mandate such activities. Rule 6.1 of the American Model Rules of Professional Conduct states that "a lawyer should aspire to render at least 50 hours of pro bono public legal services per year" and that "a substantial majority of the 50 hours" should be to persons of limited means or to organizations that support the needs of persons of limited means." ${ }^{65}$ It is a fair conclusion, however, that even if lawyers provided more pro bono legal work - either voluntarily or through bar mandated rules - many in the United States still would be frozen out of the legal system due to its cost.

\section{Conclusion}

This article has surveyed the main principles governing attorney's fees in the United States. As we have seen, while the United States has adhered to the so-called American Rule for over 200 years, and while the American Rule still maintains vitality, the law governing attorney fees is much more complex than that simple rule suggests at first blush. Further, statutes and rules concerning who pays for a party's legal fees has a fundamental bearing on the important over-arching issue of access to the courts. Many litigants, whether they win or lose, do not have to pay their legal counsel directly, and still have competent representation. However, many middle class and low income persons cannot avail themselves of legal counsel and the United States presently has inadequate systems in place (insufficient legal aid and non-mandatory pro bono requirements for lawyers) to allow many to have the legal representation needed to assert their legal rights.

\section{Acknowledgement}

The author thanks Paul Heller for his assistance in providing invaluable research and editing for this article. 


\section{LEXONOMICA \\ T. A. Heller: An Overview of the Law of Attorney Fees in the United States: \\ The American Rule is not so Simple After All}

\section{Notes}

${ }^{1}$ There are also many ethical issues associated with attorney billing, but a discussion of those issues is beyond the scope of this article. The American Bar Association has promulgated Model Rules of Professional Conduct, and those Rules have numerous provisions regarding attorney billing.

${ }^{2}$ See, https://www.statista.com.

${ }^{3}$ Id.

${ }^{4}$ Id.

${ }^{5}$ See, https://www.elocallawyers.com/elocal-reviews (accessed: 12. 6. 2018).

${ }^{6}$ Id.

${ }^{7}$ Id.

${ }^{8}$ See, https://www.towerswatson.com/en/Insights/IC-Types/Survey-ResearchResults/2012/01/2011-Update-on-US-Tort-Cost-Trends (accessed: 12. 6. 2018). ${ }^{9}$ Id.

${ }^{10}$ The Civil Division of the United States Attorney's Office for the District of Columbia [USAO] has prepared a matrix of hourly rates for attorneys of varying experience levels and paralegals/law clerks. The matrix is intended for use in cases in which a fee-shifting statute permits the prevailing party to recover "reasonable" attorney's fees. The USAO Attorney's Fees Matrix for 2015 - 2018, lists rates for paralegals and law clerks and also for attorneys with less than 2 years of experience and then with increasing levels of experience, up to 30+ years of experience. For CY 2017-2018 attorney fee rates range from a low of $\$ 302$ per hour for attorneys with less than two years of experience to a high of $\$ 602$ per hour for attorneys with more than 31 years of experience. See, https://www.justice.gov/usao-dc/file/796471/download (3. 6. 2018).

${ }^{11}$ Under a consultation fee, the attorney may charge a fixed or hourly fee for the initial meeting where the client and attorney meet to discuss the case and a determination is made whether the attorney can assist the client.

${ }^{12}$ A contingency fee is one where the attorney's fee is based on a percentage of the amount of money obtained by the attorney on behalf of the client, either by way of settlement or following a trial, arbitration or appeal. If the attorney does not obtain a settlement or loses at the trial, or on the appeal, and therefore obtains no money for the client, the attorney does not receive a fee. However, win or lose, the client will have to pay (or reimburse) the attorney's out of pocket costs expended to fund the legal action. In modern practice, many attorneys now offer a sliding scale based on how far along the case has progressed before it was resolved. The low end might be $33 \%$ or even lower and the higher end might be $50 \%$ or even higher (e.g., following a full-blown trial on the merits and appeal).

${ }^{13}$ Flat fees are usually offered only in situations where the case is relatively simple or routine, such as simple will or an uncontested divorce. Some attorneys will offer a client a flat fee for the purpose of investigating a specific legal matter, and offering the client advice on that matter.

${ }^{14}$ In many cases, the attorney will charge the client for each hour, or portion of an hour, that the attorney and office staff such as legal assistants and paralegals, works on the case. Attorney rates in the United States vary wildly based on many factors already discussed in this article. See, for example, footnote 10 . Some attorneys charge different fees for different types of work. In addition, attorneys working in larger firms typically have different fee scales with more senior members charging higher fees than younger attorneys.

${ }^{15}$ An attorney that refers a client to other attorney may ask for a portion of the total fee the clients pays to handle the case. Referral fees are common in personal injury matters, where the plaintiff's attorney usually is compensated under a written contingency fee agreement. Referral fees are governed by the ethical rules that attorneys must comply with and the total fee must be reasonable. 
16 The attorney is paid a set fee. A retainer is like a down payment, against which future fees are billed. The retainer fee is usually placed into a special account known as a Trust Account, which is typically required by the Bar Association the attorney belongs to. The attorney must maintain the retainer fees in this Trust Account, solely for the client, and must not use those funds for any other purpose. Improper use of client funds is a major cause for 4 attorney discipline and often disbarment.

${ }^{17}$ See, Johnson v. Zerbst, 304 U.S. 458 (1938).

${ }^{18}$ Gideon v. Wainwright, 372 U.S. 335 (1963).

${ }^{19}$ See also, Public defenders are overworked and underfunded. That means more people go to jail. Opinion - The Guardian. https://www.theguardian.com (accessed: 3. 6. 2018)

${ }^{20}$ In many cases a dispute will occur which triggers insurance coverage, for example, a fire, or a boating accident. On notice of a claim or potential claim, the carrier(s) for the insured has a duty to investigate, which might well include a duty to retain (and pay for) legal counsel on behalf of its insured to assist with the investigation. Many such disputes are resolved, with the assistance of assigned legal counsel, without a lawsuit being commenced.

${ }^{21}$ There are two primary components (aims) or most insurance policies: (1) a duty by the insurance company "to defend" its insured and (2) a duty by the insurance company "to indemnify" its insured. Insurance policies, as written in the United States, are complex and contain many definitions and conditions, utilizing confusing-sounding language. But in short, the duty to defend and the duty to indemnify are probably the most important components, and they are separate and distinct. As a further general proposition, the insurance company's duty to defend the insured is much broader and extensive than is its duty to indemnify. The duty to defend directly impacts how attorney's fees and court costs are paid.

${ }^{22}$ See, Arcambel v. Wiseman, 3 U.S. (3 Dall.) 306 (1796).

${ }^{23}$ See, Fleischmann Distilling Corp. v. Maier Brewing Co., 386 U.S. 714, 718 (1967).

${ }^{24}$ Of course, the usual defenses to contracts might apply to negate such clauses such as undue influence, duress, lack of capacity, etc.

${ }^{25}$ Hall v. Cole, 412 U.S. 1, 5 (1973).

${ }^{26} 412$ U.S. at 15.

${ }^{27}$ Roadway Express, Inc. v. Piper, 447 U.S. 752, 765-767 (1980). The Court also noted that under Federal Rule of Civil Procedure 37(b), '[b]oth parties and counsel may be held personally liable for expenses, 'including attorney's fees,' caused by the failure to comply with discovery orders." 447 U.S. at 763 .

${ }^{28}$ See, Annotation, 8 L.Ed.2d 894, 905 (1963).

${ }^{29}$ Trustees v. Greenough, 105 U.S. 527 (1881).

${ }^{30} \mathrm{Id}$.

${ }^{31}$ See, Toledo Scale Co. v. Computing Scale Co., 26 U.S. 399 (1923).

${ }^{32}$ See generally, La Raza Unida v. Volpe, 57 F.R.D. 94, 98 (N.D.. Cal. 1972), aff'd, 488 F.2d 559 ( $9^{\text {th }}$ Cir. 1973), cert denied, 417 U.S. 968 (1974).

${ }^{33}$ Although not technically a fee shifting statute, the Telephone Consumer Protection Act of 1991 (TCPA), codified at 47 U.S.C. $\$ 227$ is an example of Congressional legislation that has made it both easier for members of the public to seek recourse for a legal violation and has been a financial boon for enterprising lawyers. The TCPS restricts telephone solicitations (i.e., telemarketing) and the use of automated telephone equipment. The TCPA limits the use or automatic dialing systems, artificial or prerecorded voice messages, SMS text messages, and fax machines. Importantly, it also prohibits unsolicited advertising faxes. In the event of a violation of the TCPA, an aggrieved person may sue for up to $\$ 500$ for each violation or recover actual monetary loss, whichever is greater; may seek an injunction; or both. The TCPA has resulted in many class actions, with some lawyers developing boutique businesses as a direct result of the statute. See, Class Action Defense Strategy 


\section{LEXONOMICA \\ T. A. Heller: An Overview of the Law of Attorney Fees in the United States: \\ The American Rule is not so Simple After All}

Blog. Up-to-date Information on Class Action Litigation. This article can be found at: www.classactiondefensestrategy.com. (25. 5. 2018).

${ }^{34}$ For example, in the Fair Housing Amendment Acts, the language reads in part: "In a civil action under subsection (a)..., the court, in its discretion, may allow the prevailing party, other than the United States, a reasonable attorney's fee and costs. The United States shall be liable for such fees and costs to the same extent as a private person." The relevant portion of the Equal Credit Opportunity Act reads, "Recovery of costs and attorney fees [...] In the case of any successful action under subsection (a), (b), or (c), the costs of the action, together with a reasonable attorney's fee as determined by the court, shall be added to any damages awarded by the court under such subsection." On the other hand, the fee-shifting language in the Fair Labor Standards Act reads, "The court in [an action violating section 6 or 7 of this Act], shall, in addition to any judgment awarded to the plaintiff or plaintiffs, allow a reasonable attorney's fee to be paid by the defendant, and costs to the action..." Finally, the Clean Air Act reads, in pertinent part, "The court, in issuing any final order in any action brought pursuant to subsection (a) of this section, may award costs of litigation (including reasonable attorney and expert witness fees) to any party, wherever the court determines such award is appropriate."

${ }^{35}$ Texas State Teachers Association v. Garland Independent School District, 489 U.S. 782, $792-$ 793 (1989).

${ }^{36}$ See, People Against Police Violence v. City of Pittsburgh, 520 F.3d 226, 232-233 ( ${ }^{\text {rd }}$ Cir, 2008).

${ }^{37}$ See e.g., Maher v. Gagne, 488 U.S. 122, 129 (1980).

${ }^{38}$ See e.g., Rhodes v. Stewart, 488 U.S. 1, 4 (1988).

${ }^{39}$ Ruckelshaus v. Sierra Club, 463 U.S. 680, 694 (1983).

${ }^{40}$ Hensley v. Eckhart, 461 U.S. 424, 433 (1983).

${ }^{41}$ Id. at 436-437.

${ }^{42}$ Texas State Teachers Association v. Garland Independent School District, 489 U.S. 782 (1989).

${ }^{43}$ Farrar v. Hobby, 506 U.S. 103 (1992).

${ }^{44}$ See, RCW 7.28.083.

${ }^{45}$ See, Olympic S.S. Co., Inc. v. Centennial Ins. Co., 117 Wash. 2 d 37 (1991).

${ }^{46}$ See, Graff v. Allstate Ins. Co., 113 Wash. App. 799 (2002).

${ }^{47}$ Some of the Civil Rights legislation at the federal level, discussed earlier, would be a prime example.

48 The Washington statute on adverse possession is a prime example. Boundary line disputes typically invoke claims of adverse possession, and litigating such cases are often time-consuming; discovery-intensive; expensive; with the outcome often uncertain. In short, all sides to these disputes usually face uncertainty and RCW 7.28.083 clearly requires parties to these actions to step back and consider settlement in order to foreclose the risk of an adverse fee and cost award. These same considerations hold true in most if not all fee shifting statutes.

${ }^{49}$ FRCP 33.

${ }^{50}$ FRCP 34.

${ }^{51}$ FRCP 36.

52 FRCP 30.

53 FRCP 35.

${ }^{54}$ Spoliation of evidence is currently a major issue in the United States, especially as it relates to the negligent or intentional destruction of electronically stored evidence [ESI]. FRCP 26, the basic discovery rule, has been amended 5 times since 2000, largely to deal with issues arising out of ESI. FRCP 37 also has been amended recently to clarify the law of sanctions when discovery violations occur, especially sanctions for discovery violations dealing with ESI. A major case that in part helped pave the way for the changes to the FRCP's on discovery was Zubulake v. UBS Warburg LLC., 2004 U.S. Dist. Lexis 13574 (S.D. N.Y. 2004). In that case, the defendant failed to produce 
emails. The judge ultimately awarded substantial attorney fees to the plaintiff and also entered an adverse inference instruction against the defendant. An extremely large jury verdict in favor of plaintiff resulted. In Coleman v. Morgan Stanley \& Co., 2005 WL 674885 (Fl. Cir. Ct. 2005) the court sanctioned Morgan Stanley for improper handling of ESI and entered a sanction of an adverse inference jury instruction. The jury returned a verdict in favor of plaintiff for \$1.4 Billion.

${ }^{55}$ See e.g., RCWA 4.84.185 in Washington state; the so-called frivolous action or defense statute. ${ }^{56}$ See, Tiger Oil Corp. v. Department of Licensing, State of Wash., 88 Wash. App. 925 (1997). This statute gives the trial court a measure of discretion in determining whether to award attorneys' fees, and the trial court will not be reversed except for a clear showing of abuse.

${ }^{57}$ See, e.g., Manning v. Loidhamer, 13 Wash. App. 766 (1975). This also is known as the ABC rule.

${ }^{58}$ The federal and state fee-shifting statutes discussed earlier in this article are prime examples.

${ }^{59}$ See, RCWA 4.84.250.

${ }^{60}$ RCWA 4.28.185.

${ }^{61}$ Voluntary dismissals are governed in the federal court system by FRCP 41 . State courts have analogue provisions.

${ }^{62}$ See, Scott Fetzer Co., Kirby Co. Div. v. Weeks, 114 Wash. 2d 109 (1990).

${ }^{63}$ See, e.g., Each year, many Americans try to navigate US courts without a lawyer. Making Justice Equal - Center for American Progress; https://www.salon.com/2017/09/30/every-year-millionstry-to-navigate-us-courts-without-a-lawyer_partner/ (accessed: 28. 5. 2018).

${ }^{64}$ Funding for legal aid often comes from the federal government Legal Services Corporation (LSC), charities, private donors, and some state and local governments. In 1974, the U.S. Congress created LSC to provide federal funding for civil legal aid services. Literature shows that even with supplemental funding from LSC, the total amount of legal aid available for civil cases is grossly inadequate. A report from LSC in 2005 found that all legal aid office nationwide, LSC-funded or not, are together able to meet only about $20 \%$ of all of the estimated legal needs of low-income people in the United States. Source: Helaine M. Barnett, President, Documenting the Justice Gap in American: The Current Unmet Civil Legal Needs of Low-Income Americans, Legal Services Corporation, September 2005.

${ }^{65}$ For a good overview of pro bono representation, see: Supporting Justice III, A Report on the Pro Bono Work of America's Lawyers. Published March 2013; available: www.abaprobono.org.

\section{References}

Benner, L. A. (2011) Eliminating Excessive Public Defender Workloads, Criminal Justice, 26(2), pp. 24-33.

Bucklin, L. (2006) Attorney Fee Awards: A Handbook for Attorneys (US: Booklocker Inc.).

Buckwalter-Poza, R. (2016) Making Justice Equal. Center for American Progress, pp. 1-9; available at: www.americanprogress.org. (accessed: 28. 5. 2018).

Cubita, P. N., Lichtman, J. S., and Rubino, D. D. (2012) Awards of Attorney's Fees in the Federal Courts, St. John's Law Review, 56(2), pp. 277-370.

Eisenberg, T, Miller, G. P. (2013) The English Versus the American Rule on Attorney Fees: An Empirical Study of Public Company Contracts, 98 Cornell Law Review, pp. 32 -382. available at: http://scholarship.law.cornell.edu/clr/vol98/iss2/2.

Karlan, P. S. (1995) Fee Shifting in Criminal Cases, Chicago-Kent Law Review, 71(2), pp. 583602.

Nichols, S. (2015) Access to Cash, Access to Court: Unlocking the Courtroom Doors with ThirdParty Litigation Finance, 5 UC Irvine Law Review, pp. 198-236. 
LEXONOMICA
T. A. Heller: An Overview of the Law of Attorney Fees in the United States:
The American Rule is not so Simple After All

Root, D. A. (2005) Attorney Fee-Shifting in America: Comparing, Contrasting, and Combining the "American Rule" and "English Rule." 15 Indiana International \& Comparative Law Review, pp. 583-617;

available at: https://mckinneylaw.iu.edu/iicir/pdf/vol15p583.pdf. (accessed: (8.9.2017).

Speck, W. H. (1951) The Use of Discovery in United States District Courts, 60 Yale Law Journal, pp. 1132-1134.

Vargo, J. F. (1993) The American Rule on Attorney Fee Allocation: The Injured Person's Access to Justice, 42 Am. U.L. Rev. 1567, pp. 1568-1590. 
66

LEXONOMICA 